\section{Travel Grant Programs Assist International Scholars}

In an effort to broaden international participation in the Annual Meeting, the Association provided travel grants to 35 international scholars in 1997. Eighteen senior scholars and 17 graduates received funds distributed through two APSA programs. A list of international grantees and their home countries follows:

\section{Advanced Foreign Graduate Student Travel Grant Program}

Chieko Numata, University of Texas at Austin, Japan

Menghua Zeng, University of Florida, People's Republic of China

Mia M. Bloom, Columbia University, Canada

Eleonora Pasotti, Columbia University, Italy

Roger M. Scully, Ohio State University, Britain

Szue-Chin Philip Hsu, University of Denver, Taiwan

Swarna Rajagopalan, University of Illinois, India

Gul Sosay, Ohio State University,

Turkey

Jongho Lee, University of Texas at

Austin, Korea

Jae-Hyun Lyu, Purdue University, Korea

Xinsheng Liu, Texas A \& M University, People's Republic of China

Birol Akgun, Case Western Reserve University, Turkey

Tong-yi Huang, University of Texas at Austin, Taiwan

Ching-ping Tang, University of

Southern California, Taiwan

Jennifer Shulman, University of

Michigan, Canada

Dietlind Stolle, Princeton University,

Germany

John von Heyking, University of

Notre Dame, Canada

\section{Senior Scholar Travel \\ Grant Program}

Bernard Steunenberg, University of

Twente, Netherlands

Mikhail A. Beznosov, Kharkov State University, Ukraine

Elena V. Kotchkina, Moscow Center for Gender Studies, Russia
Simon Critchley, Goethe Universitaet, Germany

Jens Borchert, University of Goet-

tingen, Germany

Desmond King, St. Johns College, Oxford University, United Kingdom Kathrin Becher, Universitat Mannheim, Germany

John J. Vail, University of Newcastle, United Kingdom

Enver Kisriev, Dagestan State

University, Russia

Stewart Wood, Magdalena College, Oxford University, United Kingdom

Nathan Widder, London School of

Economics, United Kingdom

Luigi Graziano, University of Turin, Italy

Tatania Zakharov, Far Eastern Institute of Public Service, Russia

Yoshiko Kojo, University of Tokyo

Tomokazu Sakano, Kobe University

Attila Agh, Budapest University of

Economic Sciences

Andras Lanczi, Budapest University

of Economic Sciences

Lazlo Vass, Budapest University of Economic Sciences

\section{Association Awards Graduate Student Grants}

In a continuing effort to assist increased graduate student participation in the annual meeting, the Association awarded 25 grants through its Advanced Graduate Student Travel Grant Program. Funded by APSA, winners were selected from a pool of over 100 applicants. All applicants were to present papers or posters at the annual meeting.

Since the program's initiation in 1994, 89 doctoral students from the U.S. have been funded by the program. Growth in the number of applications submitted for consideration has risen over $40 \%$. At the 1997 meeting in Washington, graduate students delivered papers on approximately 650 panels and roundtables and could be found among the 300 scholars presenting posters.

The names and affiliation of the 1997 winners follow:

Fiona Adamson, Columbia University

Bear Braumoeller, University of Michigan

Allaine Cerwonka, University of
California, Irvine

Kelly Chang, Stanford University

Bryan Daves, Columbia University

Todd Eisenstadt, University of

California, San Diego

Heather Foust, Emory University

Robert Howard, SUNY-Stony Brook

Sarah Hughes, Northwestern

University

Kenneth Kyle, Arizona State

University

Laura Langer, Florida State

University

John Lapinski, Columbia University

Janet Liable, Yale University

James Martin, University of Texas

at Austin

Jason Myers, University of Califor-

nia, Berkeley

David Richards, SUNY-Binghamton

Shad Satterthwaite, University of

Oklahoma

Gary Shaub Jr., University of

Pittsburgh

Stuart Shulman, University of

Oregon

Suzanne Soules, University of

California, Santa Barbara

Richard Tahvildaran-Jesswein,

Northern Arizona University

Nina VanDyke, University of California, Santa Barbara

Kevan M. Yenerall, Miami Univer-

sity $(\mathrm{OH})$

Pamela Zeiser, Claremont Graduate

University

Amy Zeitler, Purdue University

In addition, the Association was able to assist another 30 graduate students seeking academic jobs and first-year faculty through a grant program supported by the Fund for the Improvement of Postsecondary Education. Those selected for the $\$ 100$ grant were asked to attend "Attracting Students with Innovative Introductory Political Science Courses," a session of the Conference for Chairs held on Wednesday, August 27,1997 . Those receiving a stipend participated in a discussion about their preparation and plans for teaching introductory courses. The session and discussion were activities of the APSA's project on Introductory Course Syllabi. The project and the stipends are supported by a grant from the Fund for the Improvement of Postsecondary Education. 


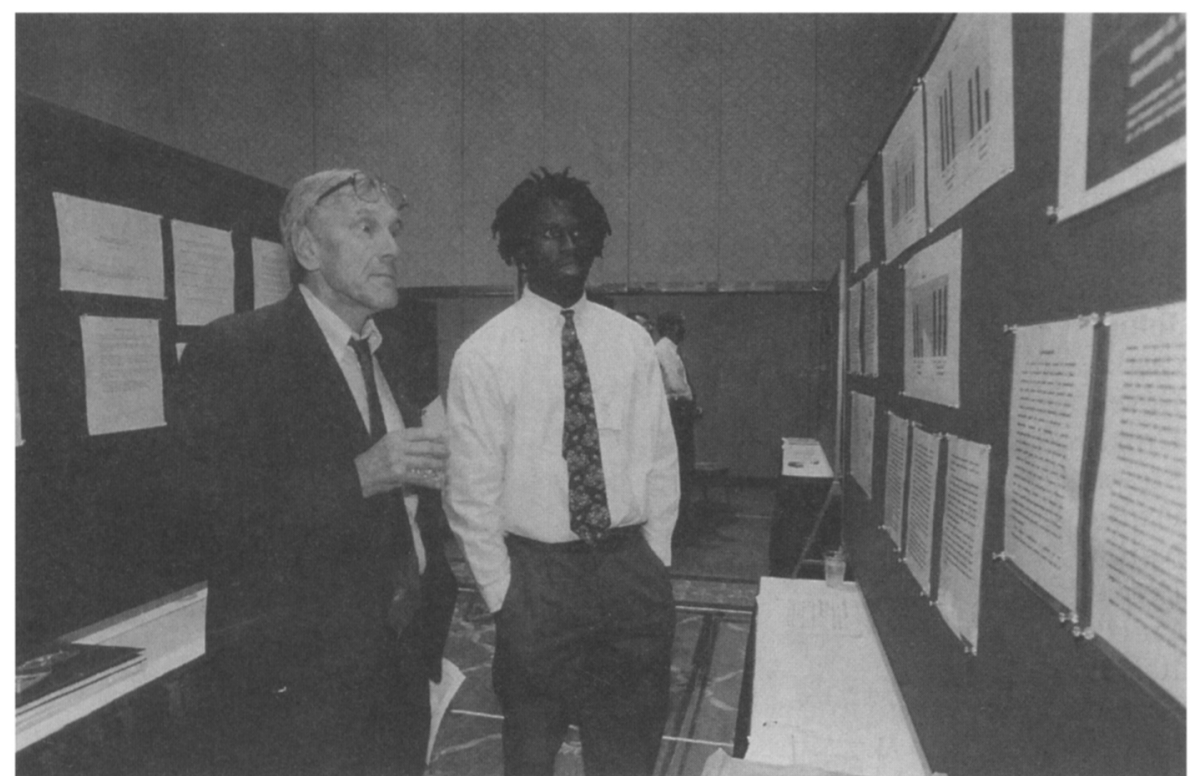

Richard Fenno (L), University of Rochester, examines Michael Salmon's poster presentation. Salmon took part in the session as a representative of the Ralph Bunche Summer Institute.

Ph.D. Candidates \& Recipients participants were:

\section{Christopher Ball, Columbia \\ University}

Mike Baumgartner, Indiana

University

Steven Benfell, University of

Pennsylvania

Richard Braunstein, University of

Colorado at Boulder

David Clark, Florida State University

Jennifer D'Urso,University of

Chicago

Wartyna Davis, Florida State

University

Francois Debrix, Ph.D., Purdue

University

Scott Desposato, University of

Californai, Los Angeles

Gregory Domin, Northern Arizona

University

Jaleh Dashti-Gibson, University of

Notre Dame

Jon Gould, University of Chicago

Stacey Hunter-Hecht, University of

Minnesota

Quentin Kidd, Texas Tech

University

Kevin Krause, University of Notre

Dame

Michael Kulisheck, University of

Pittsburgh

Kira Poplowski, University of

California, Santa Barbara
Peter Radcliffe, Ohio State

University

Amanda Rose, Indiana University

Dean Schloyer, Northwestern

University

Greg Shaw, Columbia University

Stephen Stambough, Ph.D., Univer-

sity of California, Riverside

First Year Faculty participating were:

R. William Ayres, Saint Mary's College, (MD)

Pearson Cross, Fitchburg State

College

Maggie Hanson, Northwestern

University

Rachel Anderson-Paul, University of

Illinois at Urbana-Champaign

Charles Tien, Hunter College

Bridget Welsh, Hofstra University

Jeffrey VanDenBerg, University of

Cinncinati

Oikuan Fiona Yap, Gettysburg

College

Including international students studying in the United States, the Association was able to provide $\$ 15,000$ to assist sixty-seven graduate students in attending the 1997 Annual Meeting.

\section{Ralph Bunche Students Present Papers at Annual Meeting}

Seven undergraduate students from the 1997 Ralph Bunche Summer Institute partcipated in the American Politics Poster Session at the Annual Meeting in Washington, D.C. Selected based on their scholarly excellence, the students presented their Ralph Bunche Summer Institute research papers in an academic atmosphere while meeting graduate recruiters and others within the discipline at the meeting.

Each presentation was carefully and professionally prepared and complimented by illustrative graphs, charts and other visual elements. In addition, the students were on hand to discuss not only their presentation but plans for graduate study. The participants were:

Vincent Ward, University of New Mexico, "African-American Group Consciousness and the Preference for Black Elected Officials"

Travis Simmons, North Carolina Agricultural \& Technical State University, "African-American Views on Interminority Coalitions"

Fatima Goss, University of California, Los Angeles, "Does Race Prevent Gender Equity?"

Sherrie Green, Wellesley College, "The Black Civil Rights Movement and Its Impact on Political Participation"

Michael Salmon, University of Miami, "Black Republicanism: Partisanship in the Sixth Party System"

Khalilah Brown, University of Virginia, "The Influence of Politically Active Black Churches on Community Activism among Blacks"

Dana Lee Olds, Lincoln University: Title Not Available.

The students joined 160 senior scholars, graduate students in political science, and representatives from organizations which provide funding and research support for political scientists in the poster session. Such sessions provide an informal setting where scholars may casually discuss their work and interests with others 